\title{
Microclimate Model for Urban Heat Island Simulation: A Prediction Tool Extension to Calculate the Ambient Temperature of Building
}

\author{
Nur Atikah Mohd Zinal ${ }^{1}$, Amnorzahira Amir ${ }^{2}$ and Norpadzlihatun Manap ${ }^{1 *}$ \\ ${ }^{1}$ Department of Construction Management, Faculty of Technology Management and Business, Universiti Tun Hussein Onn \\ Malaysia, 86400 Parit Raja, Batu Pahat, Johor, Malaysia
}

${ }^{2}$ Faculty of Civil Engineering, Universiti Teknologi MARA, 40450 Shah Alam, Selangor, Malaysia

\begin{abstract}
Universiti Tun Hussein Onn Malaysia (UTHM) is a public university located at Parit Raja, Batu Pahat, which is categorized as a suburban area of Johor, Malaysia and is still in development progress. However, the quick pace of development leads to changing of land use from green surface to hard surface building blocks which tends to increase the temperature level and reduce outdoor comfort level of occupants in UTHM. In addition, the available software simulations that used currently for temperature monitoring is mostly too complicated for educated non-scientist such as urban planners and architects. This research objectives are to predict the ambient building temperature of reference area by using Screening Tool for Estate Environment Evaluation software (STEVE) and to provide comparison for both of field measurements with STEVE results. In order to achieve these objectives, a total of six stations considering different urban morphologies are evaluated to give a better understanding on implication of urban heat island. The daily minimum $\left(\mathrm{T}_{\min }\right)$, average $\left(\mathrm{T}_{\text {avg }}\right)$ and maximum $\left(\mathrm{T}_{\max }\right)$ air temperature for six stations in UTHM have been developed and validated based on a long-term field measurement. The pavement (PAVE), building (BDG), green plot area ratio (GnPR), average height area (AvgHT), sky view factor (SVF), total wall area (WALL) and result of the temperature ( $\mathrm{T}_{\max }, \mathrm{T}_{\min }$ and $\mathrm{T}_{\text {avg }}$ ) are automatically calculated by STEVE from the developed 3D models. The results show that the percentage different of temperature between STEVE and field measurement is in a range of 0.9$1.0 \%$ and this has strongly indicated that STEVE is suitable to be used as temperature prediction tool.
\end{abstract}

\section{Introduction}

Urban heat island (UHI) phenomenon is a condition which outdoor temperature in urban area is higher than surrounding rural environment. This results from urbanization that caused increase of anthropogenic heat emission in urban area [1] and research by [2] supported that the greater area of asphalt roads and concrete building, the higher the increase of heat absorbed and retained by urban surrounding. The impact of UHI depends on how the town is build, how the street and building are arranged as well as the level of heat generated by combustion of hydrocarbon for the transportation and domestic uses [3]. Strongly supported by Shalaby (2011) and other previous researches, rapid urbanization in urban area extremely changes the use of land and the natural landscapes with addition of new building and paved surfaces $[4,5,6,7,8,9,10]$. The natural landscape is replaced with building thus reducing the vegetation ratio. This causes the temperature in urban area tend to be warmer than at rural area. Higher temperature on the surrounding environment gives serious impact in outdoor thermal comfort and the healthy level of building occupant. This research will use a simulation tool to predict and monitor the ambient temperature that can help to reduce the impact of nonplanning development that causing degradation of the environment. This also helps to improve weather and air quality of environment [11]. Based on previous studies, the available software simulation or model that used currently for temperature monitoring is mostly complicated for educated non-scientist such as urban planners and architects. In this study, a user-friendly temperature prediction tool that is easy to be used by non-scientist designers like architects and urban planners, the Screening Tool for Estate Environment Evaluation (STEVE), will be used. This tool is a plug-in to the Trimble Sketch Up that is formerly known as Google Sketch Up. Supported by Tan et al (2015), this simulation model is used straightforwardly as the analysis tool by urban planners on temperature monitoring and control during the design and feasibility study process [13]. This simulation model (STEVE Tool plug-in with Sketch Up) can produce and generate various patterns of climatic maps and sectional temperature profiles. Moreover, this simulation model is completed with plants database from the National Parks Board (NParks) which it is able to calculate the impact of landscaping on temperature carbon emission [11].

This study aims to investigate the ambient building temperature of the study area that effected due to different urban morphologies influenced by UHI parameters such as pavement percentage (PAVE), building percentage (BDG), average ratio of building height compared to the built area (AvgHT), sky view factor (SVF) and green plot ratio (GnPR). At Universiti Tun Hussein Onn Malaysia (UTHM), Parit Raja, Batu Pahat, Johor, the demand for building and infrastructure is increasing due to rapid development of this campus. It leads to changing of land use from green surface to hard

\footnotetext{
* Corresponding author: hp170092@,siswa.uthm.edu.my; padzliha@uthm.edu.my
} 
surface building block or faculties' structure. Supported by Manap \& Voulvoulis (2014), the land use area commonly give the first impact on the environment [12]. Due to this research, a better planning of development can be practiced especially for UTHM.

\subsection{Scope of study}

Universiti Tun Hussein Onn Malaysia campus can be considered as a township due to its size, occupancy level and mixed complex functions. In this study, six buildings on the campus of Universiti Tun Hussein Onn Malaysia are selected as the detailed study buildings as shown in Figure 1, namely library UTHM; S1, Faculty Technology and Business Management (FPTP); S2, Faculty of Technical Education and Vocational (FPTV); S3, Faculty of Civil and Environmental Engineering (FKAAS); S4, Faculty of Electrical and Electronic Engineering (FKEE); S5 and Faculty of Computer Science and Information Technology (FSKTM); S6. The selection of these buildings is due to several factors that include building area, landscape features around buildings and surface area of the influence area.

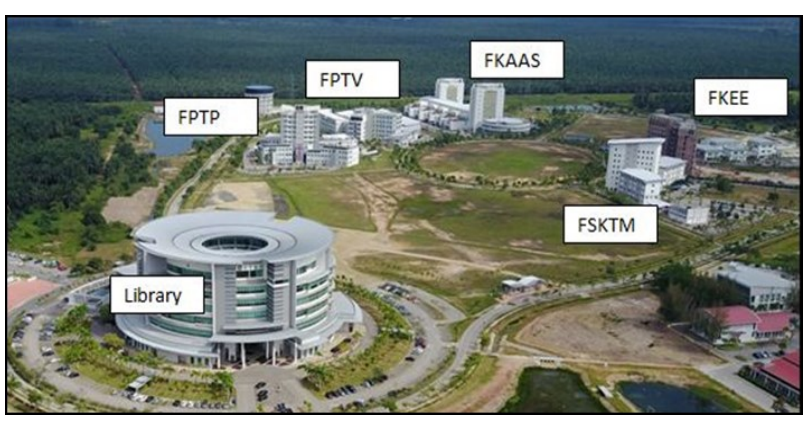

Fig.1. Aerial view of influence area

\section{Literature view}

Table 1 listed some of the previous researches of urban heat island (UHI). Many studies have been conducted on the UHI that assesses outdoor condition and different surrounding environment spaces and also under different climatic conditions.

Table 1. Previous researches of urban heat island (UHI)

\begin{tabular}{|c|l|}
\hline Researcher & \multicolumn{1}{|c|}{ Main research finding } \\
\hline$[11]$ & $\begin{array}{l}\text { The land usage will influence the urban } \\
\text { temperature and with the appropriate land } \\
\text { use planning, the urban hate island (UHI) } \\
\text { could be mitigated. }\end{array}$ \\
\hline Singapore \\
Singapore & $\begin{array}{l}\text { University campus is present as a small city. } \\
\text { The greenery gives a positive impact and } \\
\text { it's considered as important element in any } \\
\text { contemporary urban planning. }\end{array}$ \\
\hline Singapore & $\begin{array}{l}\text { Climatic responsive urban planning by } \\
\text { careful consideration on urban morphology } \\
\text { parameters of urban corridor width, building } \\
\text { height, urban surface materials, sky view } \\
\text { factor (SVF) and vegetation help to improve } \\
\text { urban environment quality. }\end{array}$ \\
\hline
\end{tabular}

\begin{tabular}{|c|c|}
\hline Singapore & $\begin{array}{l}\text { The three major elements of building, } \\
\text { greenery and pavement which are influence } \\
\text { the urban temperature at the local scale. The } \\
\text { GnPR which is related to the present of } \\
\text { greenery, have the most significant impact } \\
\text { on the energy consumption by reducing } \\
\text { temperature up to } 2^{\circ} \mathrm{C} \text {. }\end{array}$ \\
\hline Singapore & $\begin{array}{l}\text { The Screening Tools of Estate Environment } \\
\text { and Evaluation tools develop as a user } \\
\text { friendly urban design platform that take } \\
\text { after GIS. These tools help the urban } \\
\text { planners to attempt to design without } \\
\text { engaging urban climate scientist. }\end{array}$ \\
\hline Malaysia & $\begin{array}{l}\text { The three important strategies to minimize } \\
\text { the impact of UHI on human health; } \\
\text { achieving appropriate transportation for } \\
\text { mitigating air pollution, providing } \\
\text { appropriate landscape and increasing the } \\
\text { albedo of building. }\end{array}$ \\
\hline Malaysia & $\begin{array}{l}\text { Sky view factor (SVF) analysis is a useful } \\
\text { and effective tool for planners and urban } \\
\text { climatologist conducting study on high-rise } \\
\text { and high-density of sub-tropical cities. The } \\
\text { understanding of SVF can provide support } \\
\text { for the development of planning standards. } \\
\text { The increase value of SVF may reduce the } \\
\text { ambient temperature. }\end{array}$ \\
\hline Malaysia & $\begin{array}{l}\text { The factor contributing to the formation of a } \\
\text { UHI in Putrajaya, Malaysia were not solely } \\
\text { caused by urbanization, but also due to the } \\
\text { other climate change. }\end{array}$ \\
\hline Malaysia & $\begin{array}{l}\text { The vegetation helps to reduce heat lost due } \\
\text { to evapotranspiration. The vegetation } \\
\text { particularly in the presence of high moisture } \\
\text { levels which is plays a vital role in the } \\
\text { regulation of surface temperature even more } \\
\text { than may non-reflective or low albedo } \\
\text { surface. }\end{array}$ \\
\hline Singapore & $\begin{array}{l}\text { The analysing of the building performance } \\
\text { should be looking not only at a stand-alone } \\
\text { (isolated) setting but to also considered the } \\
\text { 'neighbourhood' approach, where urban } \\
\text { environment has a significant effect on the } \\
\text { energy performance of individual buildings. }\end{array}$ \\
\hline
\end{tabular}

\section{Methodologies}

\subsection{Field measurement}

Field measurement was used to collect the relevant weather data and built environment condition according to variables needed in air temperature prediction model. This includes air temperature, solar radiation, wind speed, sky view factor (SVF), building reflectivity and pavement reflectivity. The devices used in the field measurement are a 4 in 1 digital Multi - Function Environment meter that has been designed to combine the functions of Sound Level Meter, Light Meter, Humidity Meter and Temperature Meter. The data recorded is in the middle of every station (S1, S2, S3, S4, S5 and S6). The field measurement carried starting in the morning until the evening from 7.00a.m to 7.00p.m and 7.00p.m to $7.00 \mathrm{a} . \mathrm{m}$ which is 24 hours on $2^{\text {nd }}$ August 2018 by hourly temperature reading. 


\subsection{Screening Tool for Estate Environment Evaluation (STEVE)}

The Screening Tool for Estate Environment Evaluation (STEVE) [11] is a web based application that is specific to an estate and it is used to calculate the value of $\mathrm{T}_{\max }, \mathrm{T}_{\min }$ and $\mathrm{T}_{\text {avg }}$ of a point interest of an estate. For the background of data climate for the reference area, this simulation used the weather data on $2^{\text {nd }}$ August 2018 at the meteorological station data from Faculty Engineering Electrical and Electronic (FKEE), Universiti Tun Husseion Onn Malaysia (UTHM) which is named as Climate Predictor data. The detail data as shown on below:
a. $\mathrm{T}_{\min }$
$=23.80{ }^{\circ} \mathrm{C}$
b. $\mathrm{T}_{\max }$
$=32.30{ }^{\circ} \mathrm{C}$
c. $\mathrm{T}_{\mathrm{avg}}$
$=26.49{ }^{0} \mathrm{C}$
d. SOLAR $_{\text {total }}=6832 \mathrm{~W} / \mathrm{m}^{2}$
e. SOLAR $_{\max }=976 \mathrm{~W} / \mathrm{m}^{2}$

The 3D models of the influence area will be set up and built using Sketch Up software. These models will have contents on all the background data of the study area, which includes building, roads, tree, pavement and greenery pavement. The design similar to master plan and will be developed into a 3D model design using Sketch Up. The isometric views of the influence area model are shown in figure 2 below.

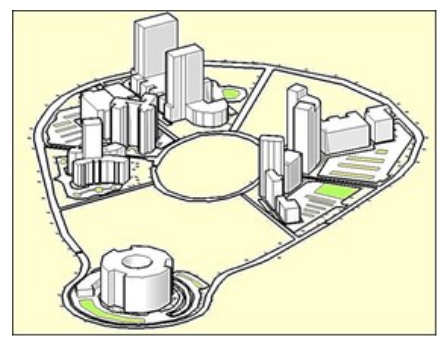

Fig.2. 3D model of reference area

After the 3D model was exported, a heat map will appeared as shown in figure 3 .

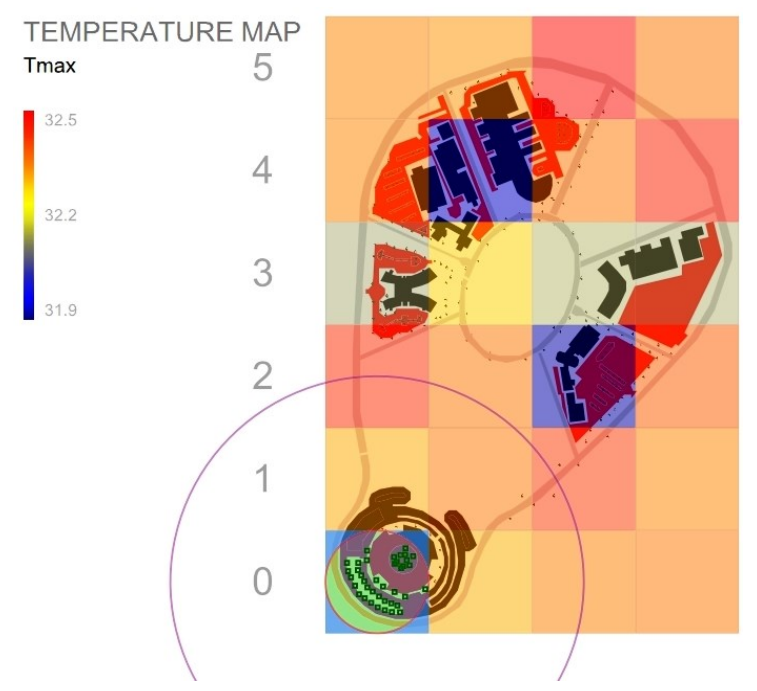

Fig. 3. Heat map by STEVE tools process

\section{Result and analysis}

\subsection{Field measurement}

Based on the hourly temperature data, the value of daily temperature of minimum (Ref $T_{\text {min }}$ ), average (Ref $\mathrm{T}_{\text {avg }}$ ) and maximum (Ref $\mathrm{T}_{\max }$ ) at reference point have been achieved (Table 2).

Table 2. Field measurement data of reference point

\begin{tabular}{|c|c|c|c|c|c|c|}
\hline \multirow{2}{*}{$\begin{array}{c}\text { Temp. } \\
\left({ }^{0} \mathrm{C}\right)\end{array}$} & \multicolumn{7}{|c|}{ Station } \\
\cline { 2 - 7 } & $\mathrm{S} 1$ & $\mathrm{~S} 2$ & $\mathrm{~S} 3$ & $\mathrm{~S} 4$ & $\mathrm{~S} 5$ & $\mathrm{~S} 6$ \\
\hline $\mathrm{T}_{\min }$ & 24.70 & 23.80 & 24.30 & 24.20 & 24.40 & 24.40 \\
\hline $\mathrm{T}_{\max }$ & 32.30 & 32.10 & 32.40 & 32.50 & 32.60 & 32.50 \\
\hline $\mathrm{T}_{\text {avg }}$ & 27.05 & 26.76 & 26.91 & 27.00 & 27.00 & 26.98 \\
\hline
\end{tabular}

\subsection{STEVE}

STEVE processed the data of the 3D model which consists of pavement percentage in 50 meter radius (PAVE), building percentage (BDG), green plot area ration (GnPR), average height area (AvgHT), sky view factor (SVF), average height to building area ratio (HBDG), Total leaf of Leaf Area Index (LAI), total wall area in each station (WALL) and result of the temperature $\left(T_{\max }, T_{\min }\right.$ and $\left.T_{\text {avg }}\right)$. All the data are automatically calculated by STEVE from the $3 \mathrm{D}$ models as shown in table 2 .

Table 2. Parameter data of each zone

\begin{tabular}{|c|c|c|c|c|c|c|}
\hline \multirow{2}{*}{ Parameter } & \multicolumn{6}{|c|}{ Station } \\
\cline { 2 - 7 } & $\mathrm{S} 1$ & $\mathrm{~S} 2$ & $\mathrm{~S} 3$ & $\mathrm{~S} 4$ & $\mathrm{~S} 5$ & $\mathrm{~S} 6$ \\
\hline $\begin{array}{c}\text { BDG } \\
(\%)\end{array}$ & 64.40 & 16.47 & 37.53 & 31.98 & 44.00 & 15.68 \\
\hline Pave (\%) & 21.91 & 8.45 & 4.20 & 7.56 & 26.57 & 9.80 \\
\hline Green (\%) & 13.69 & 75.08 & 58.27 & 60.47 & 29.67 & 76.52 \\
\hline $\begin{array}{c}\text { AvgHT } \\
(\mathrm{m})\end{array}$ & 18 & 23 & 24 & 15 & 19 & 17 \\
\hline HBD & 0.355 & 2.082 & 0.650 & 0.477 & 1.165 & 1.293 \\
\hline $\begin{array}{c}\text { WALL } \\
\left(\mathrm{m}^{2}\right)\end{array}$ & 8310 & 8376 & 12188 & 7517 & 9270 & 8474 \\
\hline $\begin{array}{c}\text { Total leaf } \\
\left(\mathrm{m}^{2}\right)\end{array}$ & 1770 & 1560 & 1650 & 1260 & 360 & 1200 \\
\hline \begin{tabular}{c} 
GnPR \\
\hline SVF
\end{tabular} & 0.449 & 1.700 & 1.356 & 1.397 & 0.577 & 1.683 \\
\hline $\begin{array}{c}\mathrm{T}_{\text {min }} \\
\left({ }^{0} \mathrm{C}\right)\end{array}$ & 24.10 & 23.40 & 23.90 & 23.90 & 24.20 & 23.80 \\
\hline $\begin{array}{c}\mathrm{T}_{\text {max }} \\
\left({ }^{0} \mathrm{C}\right)\end{array}$ & 32.60 & 32.10 & 32.10 & 32.70 & 32.70 & 32.70 \\
\hline $\begin{array}{c}\mathrm{T}_{\text {avg-day }} \\
\left({ }^{0} \mathrm{C}\right)\end{array}$ & 28.60 & 28.20 & 28.40 & 28.20 & 28.30 & 28.30 \\
\hline $\begin{array}{c}\mathrm{T}_{\text {avg-night }} \\
\left({ }^{0} \mathrm{C}\right)\end{array}$ & 25.80 & 25.40 & 25.40 & 25.80 & 25.90 & 25.70 \\
\hline $\begin{array}{c}\mathrm{T}_{\text {avg }} \\
\left({ }^{0} \mathrm{C}\right)\end{array}$ & 27.20 & 26.80 & 26.90 & 27.00 & 27.10 & 27.00 \\
\hline
\end{tabular}

\subsection{Comparison between field measurement and STEVE data}

The results as in figure 4 showed the difference between the temperature of field measurement data on 
2nd August 2018 and the result of the study area temperature that calculated by using STEVE which are deviated from the background air temperature measured at FKEE (UTHM) meteorological station.

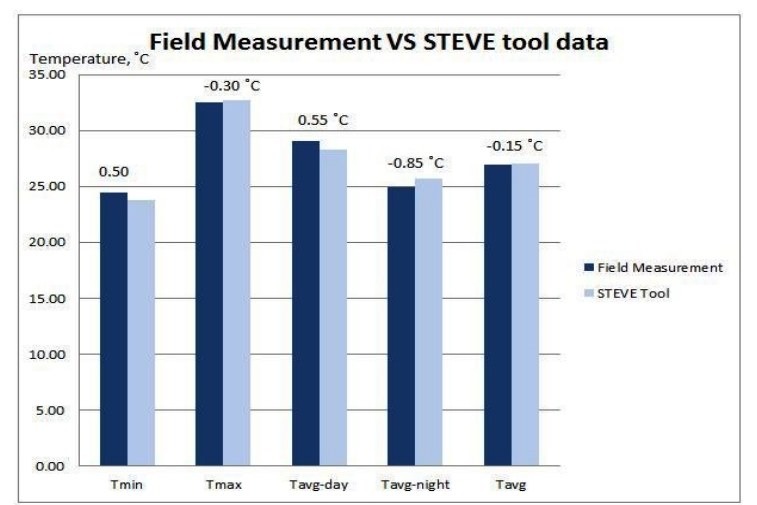

Fig.4. Library UTHM station (S1)

Based on that comparison data at library station (figure 4 ), the result of $\mathrm{T}_{\min }$ and $\mathrm{T}_{\text {avg-day }}$ for the field measurement is higher than the result calculated by STEVE which is about $+0.60{ }^{\circ} \mathrm{C}$ for $\mathrm{T}_{\min }$ and $0.55{ }^{\circ} \mathrm{C}$ for $\mathrm{T}_{\text {avg-day. }}$ However, for the result of $\mathrm{T}_{\max }, \mathrm{T}_{\text {avg-night }}$ and $T_{a v g}$, the field measurement temperature result is lower than STEVE data about $-0.30{ }^{0} \mathrm{C}$ for $\mathrm{T}_{\max },-0.85$ ${ }^{0} \mathrm{C}$ for $\mathrm{T}_{\text {avg-night, }}$ and $-0.15{ }^{0} \mathrm{C}$ for $\mathrm{T}_{\text {avg. }}$. The different temperature data between field measurement and STEVE probably in the range $0.96-1.0 \%$. The different of this temperature data from this two methods were found as not significant, hence the results predicted by STEVE is acceptable.

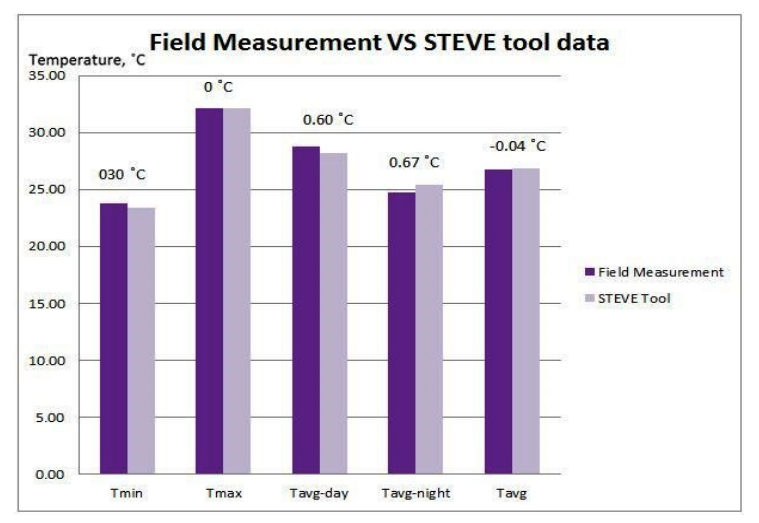

Fig. 5. FPTP station (S2)

On the FPTP station (figure 5), compared to the STEVE data, the result of the field measurement temperature at the FPTP's station is higher for the $\mathrm{T}_{\text {min }}, \mathrm{T}_{\text {avg-day, }}$ and $\mathrm{T}_{\text {avg-night }}$ about $+0.30{ }^{0} \mathrm{C},+0.60{ }^{0} \mathrm{C}$ and $+0.67{ }^{\circ} \mathrm{C}$. For the result of the $\mathrm{T}_{\max }$, they have a similar temperature at $32.10{ }^{0} \mathrm{C}$. The results of the $\mathrm{T}_{\text {avg }}$ for the field measurement temperature data are lower than STEVE, about $-0.04{ }^{0} \mathrm{C}$. The temperature different probably in the range $0.97-1.0 \%$ and the results found as not significant. Therefore, results predicted by STEVE is acceptable.

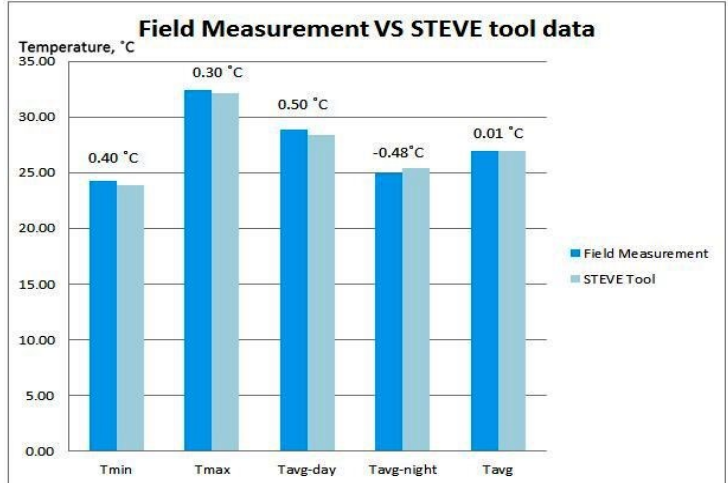

Fig.6. FPTV station (S3)

Figure 6 shows the temperature data at FPTV's station and the comparison temperature data between field measurement result and STEVE data calculation. Mostly all the data of the field measurement is higher than the data calculated by the STEVE prediction models. The $\mathrm{T}_{\min }$ is $+0.40{ }^{0} \mathrm{C}, \mathrm{T}_{\max }$ is about $+0.30{ }^{\circ} \mathrm{C}$, $+0.50{ }^{0} \mathrm{C}$ for $\mathrm{T}_{\text {avg-day }}$ and $+0.01{ }^{0} \mathrm{C}$ for $\mathrm{T}_{\text {avg }}$ of the temperature results field measurement higher than STEVE. Only the result of the $\mathrm{T}_{\text {avg-night, the field }}$ measurement temperature data has a lower result than the STEVE, about $-0.40{ }^{0} \mathrm{C}$. The different of this temperature data from this two methods found as not significant hence, results predicted by STEVE is acceptable with range of $0.98-1.0 \%$ of temperature difference.

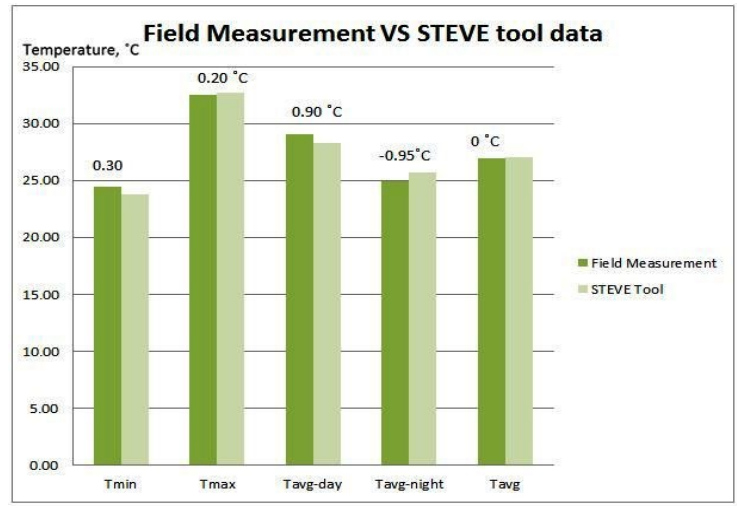

Fig.7. FKAAS station (S4)

Figure 7 shows the comparison data collected using field measurement and STEVE calculation for FKAAS's station. This result shows that they have same temperature of $\mathrm{T}_{\text {avg }}$ at $27.00{ }^{0} \mathrm{C}$. Next, for the $\mathrm{T}_{\min }$ and $\mathrm{T}_{\text {avg-day, }}$ the field measurement has a higher temperature result about $+0.30{ }^{0} \mathrm{C}$ for $\mathrm{T}_{\min }$ and +0.95 ${ }^{0} \mathrm{C} \mathrm{T}_{\text {avg-day }}$ than STEVE temperature calculation. But then, the field measurement has a lower result of temperature at $-0.20{ }^{\circ} \mathrm{C}$ for $\mathrm{T}_{\max }$ and $-0.95{ }^{\circ} \mathrm{C}$ for $\mathrm{T}_{\text {avg- }}$ night than STEVE temperature prediction result. Thus, STEVE result is acceptable and the result found as not significant with temperature difference probably in the range of $0.96-1.0 \%$. 


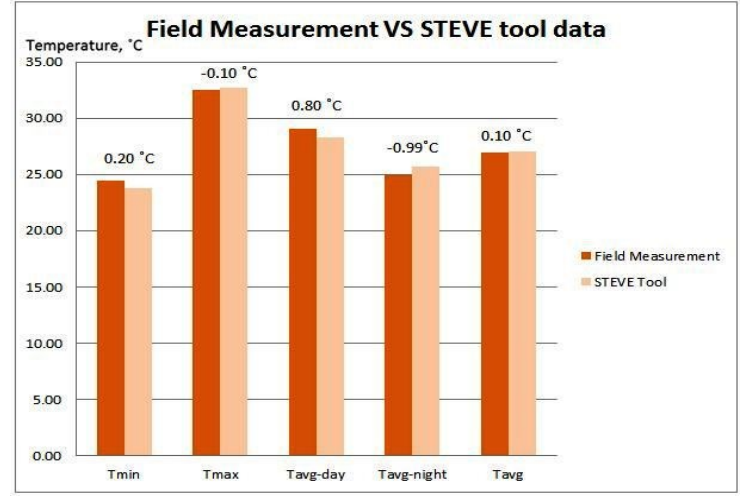

Fig.8. FKEE station (S5)

For the comparison data at FKEE's station as in figure 8 , all of them have a higher temperature for field measurement data collection result than STEVE prediction calculation. About $+0.20{ }^{\circ} \mathrm{C}$ for $\mathrm{T}_{\min },+0.80$ ${ }^{0} \mathrm{C}$ for $\mathrm{T}_{\text {avg-day }}$ and $+0.10{ }^{\circ} \mathrm{C}$ for $\mathrm{T}_{\text {avg }}$ of the filed measurement temperature data is higher than STEVE data. For $\mathrm{T}_{\max }$ and $\mathrm{T}_{\text {avg-day, }}-10{ }^{\circ} \mathrm{C}$ and $-0.99{ }^{\circ} \mathrm{C}$ of the field measurement temperature lower than the prediction data by STEVE. The different temperature data between field measurement and STEVE probably in the range $0.96-1.0 \%$. The difference of this temperature data from this two methods found as not significant and results predicted by STEVE is acceptable.

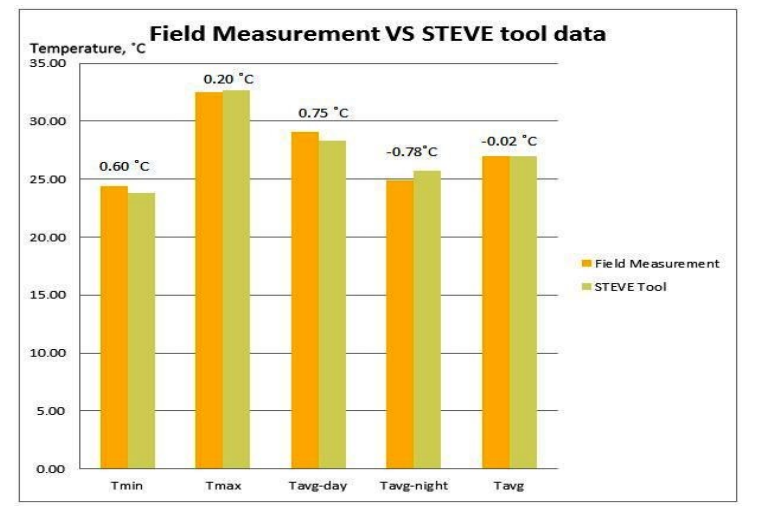

Fig.9. FSKTM station (S6)

Based on figure 9, comparison data has been studied and the results shows that $T_{\min }, T_{\max }$ and $T_{\text {avg-day }}$ are higher about $+0.6{ }^{0} \mathrm{C},+0.2{ }^{\circ} \mathrm{C}$, and $+0.75{ }^{\circ} \mathrm{C}$ for the field measurement result than the predicted STEVE data. For the $\mathrm{T}_{\text {avg-night }}$ and $\mathrm{T}_{\text {avg }}$, the field measurement temperature result has lower result than the STEVE data, about $-0.78{ }^{\circ} \mathrm{C}$ for $\mathrm{T}_{\text {avg-night }}$ and $0.02{ }^{\circ} \mathrm{C}$ for $\mathrm{T}_{\text {avg }}$ result. The different between field measurement and STEVE data probably in the range $0.96-1.0 \%$. Hence, the different of this temperature data from two methods found as not significant and results predicted using STEVE is acceptable.

It can be seen from the results obtained that temperature calculated using STEVE are mostly similar to the temperature on real environment at the study area due to the condition that has been developed on the 3D models in Sketch Up. The 3D models are following the master plan of the study area. The temperature calculated nearly similar but also have difference about $+0.5{ }^{\circ} \mathrm{C}$ and $-0.5{ }^{\circ} \mathrm{C}$, but not more than $+1^{\circ} \mathrm{C}$ and less than $-1^{\circ} \mathrm{C}[14]$.

\section{Conclusion}

From the field measurement and STEVE simulation, it can be concluded that STEVE is suitable to be used as temperature prediction model, which it has a percentage range of $0.90-1.0 \%$ of temperature difference. As can be seen, it has a small difference of temperature comparing between field measurement and STEVE simulations. Based on this, it can be concluded that STEVE could be a better and a suitable choice for studying the tropical urban area and a better planning for development can be practiced, especially for UTHM campuses.

\section{References}

1. L.W.A. van Hove, C.M.J. Jacobs, B.G. Heusinkveld, J.A. Elbers, B.L. van Driel, A. A. M. Holtslag. Building and Environment, 83, 91-103 (2015)

2. M. Igantius, A. Eliza. International Journal of Sustainable Building Technology and Urban Development, 3, 197-209 (2012)

3. T. R. Oke. Atmospheric Environment Pergamon Pres, 7, 769-779 (1973)

4. Shalaby. Journal of Climatology, 8, 42-63 (2011)

5. N. Manap and N. Voulvoulis, Applied Mechanics and Materials, 567, pp. 50-55 (2014)

6. N. Manap, K.Y. Tan and N. Shahrom, IOP Conference Series: Earth and Environmental Science, 109, 012026 (2017)

7. N. Manap, N.H. Mohd Noh and N. Syahrom, IOP Conference Series: Earth and Environmental Science, 109, 012011 (2017)

8. N. Manap, N.I. Muhamad and K., Sandirasegaran, Materials Science Forum, 889 pp. 261-264 (2017)

9. N. Manap, N. Jeyaramah and N. Syahrom, IOP Conference Series: Earth and Environmental Science, 109, 012027 (2017)

10. N. Manap, Y.K. Goh and N. Syahrom, IOP Conference Series: Earth and Environmental Science, 109, 012008 (2017)

11. S. K. Jusuf, N. H. Wong, E. Hagen, R. Anggoro, Y. Hong. Habitat International, 31(2), 232-242 (2007).

12. N. Manap, N. Voulvoulis. Science of the Total Environment, 496, 607-623 (2014)

13. E. Tan, S. K. Jusuf, M. Ignatius, N. H. Wong. 1-7 (2015).

14. N. H. Wong, S. K. Jusuf, C. L. Tan. Landscape and Urban Planning, 10-13, (2011)

15. N. H. Wong, S. K. Jusuf, N. Imam, Y. Chen. Solar Energy, 85 57-71(2011)

16. N. H. Wong, S. K. Jusuf, R. Samsudin, A. Eliza, 
M. Ignatius. International Journal of Sustainable Building Technology and Urban Development, 2(4), 323-330 (2011)

17. C. Liang, N. Edward, A. Xipo , R. Chao, L. Max, W. Una, H. Zhengjun. International Journal of Climatology, 32(1), 121-136 (2012)

18. S. A. Salleh, Z. Abd. Latif, N. W. M. W. M. Naim, A. Chan. Procedia - Social and Behavioral Sciences, 105, 840-850 (2013)

19. P. Rajagopalan, K. C. Lim, E. Jamei. Solar Energy, 107, 159-170 (2014)

20. J. Kraus. Department of Geography and Regional Science, Faculty of Environmental, Regional and Educational Sciences, University of Graz: Master Thesis (2015)

21. S. K. Jusuf, M. Ignatius, N. H. Wong. 4th International Conference on Countermeasures to Urban Heat Island, 30-31 (2016) 